\title{
AMERICAN FORUM NON CONVENIENS IN LIGHT OF THE HAGUE CONVENTION ON CHOICE-OF-COURT AGREEMENTS
}

\author{
Christopher Tate*
}

\section{INTRODUCTION $^{1}$}

Little Grill Guy, LLP, (LGG) is a small Pittsburgh firm whose primary business is making and selling high-end gas grills for outdoor use. Recently, a famous chef used LGG's top-of-the-line model when preparing a meal on a very popular Japanese cooking game show. As often happens when American culture is injected into the Japanese limelight, Japanese consumers have been clamoring for LGG products since the episode aired. LGG has started negotiations with Tokyo-Mart, Inc., the largest commercial retailer in Japan. Despite its recent fame in Japan, LGG is still a small firm in a small industry and has relatively little bargaining power compared to the retail giant.

These negotiations are difficult for LGG. While it knows that the Japanese market would yield sales that it desperately needs to stay afloat, currently its production line has such high overhead that it cannot manufacture and sell grills at a very high margin. Therefore, the sale price of the grills to Tokyo-Mart is a point upon which lawyers for LGG cannot compromise. The astute counsel for Tokyo-Mart knows this and uses LGG's inflexibility to negotiate harsh terms into the agreement. It is in this environment that the firms negotiate a choice-of-forum clause into the agreement.

If Tokyo-Mart were actually the conspicuous American retail chain of similar name, the negotiations between it and LGG on choice of forum would involve a balancing of different concerns between arbitration and litigation. For example, LGG might balk at the relative exorbitance of arbitral filing fees,${ }^{2}$ or the fact that, as at least one commentator has noted, arbitrators have

\footnotetext{
* J.D., University of Pittsburgh School of Law, 2007; B.A., University of Virginia, 2004. The author wishes to thank Professors Ronald Brand and Rhonda Wasserman of the University of Pittsburgh School of Law for their mentoring and advice regarding this Note. Also, the staff of Volume 69 of the Law Review, especially David Weinstein and Fred Shrayber, provided tremendous effort and insight in bringing this Note to publication - their hard work deserves notice.

1. This hypothetical is not based on any reported decision; it is simply for illustration.

2. Arbitration filing fees vary by firm and size of the dispute. As an example, filing fees for a $\$ 250,000$ dispute to be resolved by the International Centre for Dispute Resolution total $\$ 2,750$, plus a
} 
leeway to craft more creative judgments. ${ }^{3}$ The retailer, on the other hand, might fear the prospect of long, arduous litigation and the bad press that accompanies such a public proceeding.

However, because this negotiation is between parties of two different nationalities, LGG's concerns over arbitration are tempered by the fact that, were it even able to negotiate a choice-of-forum clause and receive a favorable judgment in court, enforcing that litigated judgment is currently far more difficult than enforcing an arbitral award because of the protections provided to arbitration proceedings by the New York Convention on the Recognition and Enforcement of Arbitral Awards (New York Convention). ${ }^{4}$ At present, the New York Convention is one of the most widely ratified treaties in history and requires the courts of a member state to respect a decision of an arbitrator in another. This treaty has, since 1968, no doubt swayed many firms engaged in international business who would otherwise choose litigation over arbitration. While there is no definitive evidence of how many transactions have been so influenced, experts have estimated that around $90 \%$ of these kinds of contracts contain an arbitration clause. ${ }^{5}$

This rubric is about to change. On June 30, 2005, thirty-nine members of the Hague Conference on Private International Law signed the Convention on Choice of Court Agreements (Hague Convention). ${ }^{6}$ The Hague Convention is currently awaiting ratification, and most commentators expect that process to eventually succeed ${ }^{7}$ as many states, especially the U.S., are interested in placing their litigated judgments on an equal playing field with arbitral

$\$ 1,250$ "case service fee." This is to be paid at the outset of the arbitration and does not include the rate for the arbitrator(s) or incidental expenses. AMERican Arbitration AsSOCIATION, InTERnAtional Dispute Resolution Procedures (2006), available at $\mathrm{http} / / / \mathrm{www} . \mathrm{adr} . \mathrm{org} / \mathrm{sp}$.asp?id=28144. As a comparison, filing a similar claim in the United States Federal District Court for the Western District of Pennsylvania would cost $\$ 350$. United States District Court for the Western District of Pennsylvania, Fee Schedule (2006), available at http://www.pawd.uscourts.gov/Pages/fee.htm.

3. On characteristics of arbitrated judgments, and what actually constitutes an arbitral "award," see Susan L. Karamanian, The Road to the Tribunal and Beyond: International Commercial Arbitration and United States Courts, 34 Geo. Wash. InT'L L. Rev. 17 (2002).

4. New York Convention on the Recognition and Enforcement of Arbitral Awards, June 10, 1958, 21 U.S.T. 2517 [hereinafter New York Convention].

5. See Klaus Peter Berger, International Economic Arbitration 8 n.62 (1993).

6. Hague Conference on Private International Law, Convention on Choice of Court Agreements, June 30, 2005, 44 I.L.M. 1294, available at http://www.hcch.net/index_en.php?act=conventions .text\&cid=98 [hereinafter Hague Convention].

7. See, e.g., Ronald A. Brand, A Global Convention on Choice of Court Agreements, 10 ILSA J. INT'L \& COMP. L. 345, 345-46 (2004). 
awards. ${ }^{8}$ An equal playing field is exactly what the Hague Convention would create.

Returning to the hypothetical, assume that the Hague Convention has been adopted by both the U.S. and Japan. Tokyo-Mart does some research and discovers that state trial courts in Bentonville, Arkansas, are, for some reason, consistently persuaded by the arguments of large retail chains. TokyoMart inserts a forum-selection clause into its standard form contract for all purchase agreements, whereby all disputes will be heard in the state courts in Bentonville, Arkansas. Little Grill Guy, so concerned in haggling the price of the sale, either misses the forum-selection clause or ignores it, assuming performance will not be an issue. In any event, the term is never negotiated.

Six months go by and Little Grill Guy is performing just as it said it would. Tokyo-Mart's performance in the Japanese market, however, is less than stellar. Profits are down, recent bad press regarding the firm's failure to contribute to the Japanese social security system has hurt its image, and competitors are gaining ground. Executives are desperate. Poring over their recent paperwork, they realize that LGG missed its February shipment to Tokyo-Mart's stateside export firm by one day. (The shipment was due Sunday, February 1, which just happened to be Super Bowl Sunday, a serious impediment to any business in the Pittsburgh area.) Calling this failure a "total breach of contract," Tokyo-Mart's American counsel files a complaint in Arkansas state court. The grills marked for shipment to Japan never passed through Arkansas, although LGG does do business in the state and is subject to personal jurisdiction.

Pittsburgh counsel for LGG arrives harried and late in the Bentonville court only to be told that her application to appear pro hac vice has been denied. LGG executives find a local attorney who had no part in the negotiation of the contract and no prior knowledge of the business relationship or inner workings of his new client. He soon realizes that while the suit could have merit, the litigation of the claim in Arkansas is vastly inconvenient and likely designed simply to harass or vex his client. Accordingly, he files a motion to dismiss based on forum non conveniens. This doctrine instructs that although many courts may have the power to adjudicate a dispute, they may not be the appropriate venues given matters of convenience and comity. ${ }^{9}$

8. See Ronald A. Brand, Community Competence for Matters of Judicial Cooperation at the Hague Conference on Private International Law: A View from the United States, 21 J.L. \& Com. 191, 192 (2002) (discussing U.S. requests for the Hague Conference on Private International Law to create a judgments convention).

9. See Gulf Oil Corp. v. Gilbert, 330 U.S. 501, 504 (1947). 
Tokyo-Mart's attorneys respond that the text of the Hague Convention prevents the court named in the choice-of-court clause from dismissing a case arising out of a valid contract. ${ }^{10}$

Tokyo-Mart's argument is likely to prevail. The rationale behind the Hague Conference's decision to deny courts the discretion to decline jurisdiction stems from the concern that forum non conveniens and similar doctrines are confusing and unpredictable as applied. ${ }^{11}$ Rather than allow a court to use complicated measures to decline jurisdiction over two parties who have negotiated to litigate under that court's rules and watchful eye, the Hague Convention makes jurisdiction mandatory for courts named in a choice-offorum agreement. ${ }^{12}$ Therefore, Little Grill Guy will be exposed to a court chosen solely for its bias, could be massively inconvenienced, and could be the recipient of an unfair or imbalanced judgment, now enforceable anywhere in the world.

In making the decision to entirely cut out forum non conveniens and other methods of declining jurisdiction, the Hague Conference missed a valuable opportunity to appropriately codify a system for declining jurisdiction in international contract cases, and its bright-line rule will likely produce unfair and inefficient results. It is likely that parties with large amounts of bargaining power will take advantage of the lack of forum non conveniens and engage in forum shopping when negotiating their contracts, a phenomenon forum non conveniens specifically combats. ${ }^{13}$ Moreover, while the Hague Convention does limit its application to cases sounding in contract, ${ }^{14}$ courts seized for a primary claim of breach of contract are given no guidance on their ability to decide or dismiss supplemental tort or personal injury claims. Finally and most importantly, in instances where hearing a case is so inconvenient that it could burden interstate commerce, the constitutionality of the Hague Convention as applied is implicated. ${ }^{15}$

Given the concerns above, this Note argues that the U.S. should ratify the Hague Convention on Choice of Court Agreements with accompanying

10. Hague Convention, supra note 6, art. 5(2).

11. See, e.g., Hague Conference on Private International Law, Preliminary Draft Convention on Choice of Court Agreements: Draft Report at 23, Prelim. Doc. No. 26 (Dec. 2004), available at http://www.hcch.net/upload/wop/jdgm_pd26e.pdf[hereinafter Draft Report] (prepared by Masato Dogauchi \& Trevor C. Hartley).

12. Hague Convention, supra note 6, art. 5(1).

13. See Piper Aircaft Co. v. Reyno, 454 U.S. 235, 250 (1981).

14. Hague Convention, supra note 6, art. 1(1), 2(2).

15. See Gulf Oil Corp. v. Gilbert, 330 U.S. 501, 505 (1947); Davis v. Farmers' Co-op. Equity Co., 262 U.S. 312, 315 (1923). 
legislation, a declaration on the meaning of Article 5 of the Hague Convention, and a declaration that indicates exactly when U.S. courts will be empowered to decline jurisdiction. This declaration should be narrowly tailored and should ensure that the dispute can and will be heard in another forum. Such a declaration likely comports with the Hague Convention's proscription of declarations limiting jurisdiction. ${ }^{16}$ Part I of this Note explores the development of various doctrines of declining jurisdiction in the U.S. with a focus on forum non conveniens, as well as current legal developments in the field of choice-of-court clauses. Part II analyzes the interaction of the text of the Convention with these doctrines, giving special attention to the rationale behind the limitation of courts' discretion, and problems with this rationale. Part III proposes a model text for the U.S. declaration, clearly delineating cases in which courts should decline jurisdiction.

\section{Forum Non Conveniens and Other Doctrines for DECLINING JURISDICTION}

\section{A. American Forum Non Conveniens}

Forum non conveniens is a common law doctrine. While some effort has been made at the federal level to deal with the problem of an inconvenient forum with legislation on transfer, ${ }^{17}$ forum non conveniens remains primarily a creation of the courts. States have various policies on declining jurisdiction; however, the Supreme Court laid out a single policy for federal courts in Gulf Oil Corp. v. Gilbert. ${ }^{18}$ This policy is now followed in many states. ${ }^{19}$

In Gulf Oil, a Virginia plaintiff sued a Pennsylvania defendant in the United States District Court for the Southern District of New York. ${ }^{20}$ The plaintiff claimed that the defendant's negligence in transporting gasoline caused a fire that destroyed his warehouse in Lynchburg. ${ }^{21}$ Although jurisdiction and venue were proper, the district court nonetheless dismissed the suit. ${ }^{22}$ In affirming the district court's decision, the Supreme Court held

16. Hague Convention, supra note 6, art. 19.

17. 28 U.S.C. $\S \S 1404,1406$ (2006). For a deeper analysis of these provisions, see infra Part I.B.

18. 330 U.S. at 501.

19. See, e.g., Islamic Republic of Iran v. Pahlavi, 467 N.E.2d 245 (N.Y. 1984) (upholding a forum non conveniens dismissal based on the Gulf Oil standard even though plaintiffs argued no superior forum existed).

20. Id. at 502 .

21. Id.

22. Id. at 503 . 
that federal courts may apply forum non conveniens where venue and jurisdiction are proper, but another court is far more convenient and appropriate. ${ }^{23}$ The Court was concerned that requiring courts to rely solely on the "open door" of the broadly constructed rules of venue and jurisdiction "may admit those who seek not simply justice but perhaps justice blended with some harassment. A plaintiff sometimes is under temptation to resort to a strategy of forcing the trial at a most inconvenient place for an adversary, even at some inconvenience to himself." ${ }^{24}$ The Court listed multiple factors to be considered when applying the doctrine - namely, interests of the private litigant, such as the "relative ease of access to sources of proof; availability of compulsory process for attendance of unwilling, and the cost of obtaining attendance of willing, witnesses"; ${ }^{25}$ and interests of the public sector, such as congestion of the docket and tortuous conflict-of-laws problems. ${ }^{26}$ Weighing these factors, the balance must tilt decisively in favor of the defendant if forum non conveniens dismissal is to be exercised. ${ }^{27}$

The seminal application of Gulf Oil in the international context is Piper Aircraft Co. v. Reyno. ${ }^{28}$ In Piper, Scottish plaintiffs brought a wrongful death claim against both the manufacturer of the airplane that crashed and caused the decedent's death, as well as the manufacturer of the propeller of the airplane. $^{29}$ Defendant Piper manufactured the plane in Pennsylvania; Defendant Hartzell manufactured the propeller in Ohio. ${ }^{30}$ The plane, which was registered in Great Britain, crashed in Scotland. ${ }^{31}$ Nevertheless, the plaintiffs filed suit in a California state court. ${ }^{32}$ The plaintiffs readily admitted that their decision was made because of the availability of more favorable tort standards (such as strict liability and expanded capacity to sue). ${ }^{33}$ After the defendants removed the case to federal court and transferred it to the Middle District of Pennsylvania, ${ }^{34}$ the district court dismissed on forum non conveniens grounds. ${ }^{35}$ In upholding the dismissal, the Supreme Court said that

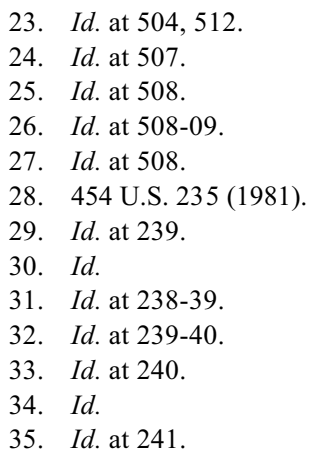


the general deference to the plaintiff's choice of forum is lessened where the plaintiff is foreign. ${ }^{36}$ In addition, the Court held that an unfavorable change in substantive law should not be given conclusive weight in a forum non conveniens analysis; the question is whether an alternative forum exists and is more convenient, not whether that forum offers the same legal framework. ${ }^{37}$

\section{B. 28 U.S.C. $\$ \S 1404,1406$ : The Statutory Codification of Transfer in the} Federal System

Originally, courts could use forum non conveniens to dismiss where the appropriate forum was another federal court, assuming (or often stipulating) that the more appropriate district would take up the case. ${ }^{38}$ Congress enacted 28 U.S.C. $\S \S 1404,1406$ to standardize the process whereby district courts move cases from one district to another. ${ }^{39}$ Generally speaking, these cases fall into two categories: Where the plaintiff originally sues in a forum where venue is properly laid, the court may transfer pursuant to $\S 1404(a)$ "for the convenience of the parties and witnesses, in the interest of justice, to any other district or division where it might have been brought." ${ }^{40}$ Where the plaintiff originally sues in a forum where venue is improper, the court must either dismiss or transfer to a proper district or division according to $\S 1406(\mathrm{a}){ }^{41}$

The jurisprudence interpreting these two statutes is substantial. ${ }^{42}$ For purposes of this Note, beyond the basic statutory structure, it is essential to understand the framework a court uses to determine the applicable law in the case of a transfer. In Van Dusen v. Barrack, ${ }^{43}$ the Supreme Court considered whether the transferee or transferor court's law would apply after a $\S 1404(a)$ transfer. ${ }^{44}$ Given that the statute is one concerned with the convenience of the parties, the Court held that a $\S 1404$ transfer is simply a change of location, and if the plaintiff files in a proper venue the first time, her choice should not be disturbed, and the law of the transferor court should apply. ${ }^{45}$ Further, the

36. Id. at 255 .

37. See id. at $249-50$.

38. See, e.g., id. at 252-53.

39. 28 U.S.C. $\S \S 1404,1406(2006)$; see id. at 253.

40. $\S 1404(a)$.

41. $\S 1406(\mathrm{a})$

42. See, e.g., Stewart Org., Inc. v. Ricoh Corp., 487 U.S. 22 (1988); Van Dusen v. Barrack, 376 U.S. 612 (1964); Norwood v. Kirkpatrick, 349 U.S. 29 (1955); Ex parte Collett, 337 U.S. 55, 71 (1949).

43. 376 U.S. 612 (1964).

44. Id. at 615 .

45. See id. at $616,633-39$. 
Van Dusen Court held that $\S 1404$ transfers can be used to cure a technical difficulty that prevents the plaintiff from filing in the transferee court. ${ }^{46}$ Conversely, if the transfer is pursuant to $\S 1406$, the plaintiff should not be rewarded for an incorrect choice of venue, and the transferee court's law should apply. ${ }^{47}$

\section{American Jurisdictional Jurisprudence As It Relates to Choice-of-Court Clauses}

American courts are currently highly amenable to freedom of contract as it relates to choice-of-court clauses. In M/S Bremen v. Zapata Off-Shore Co. ${ }^{48}$ the Supreme Court held that where choice of forum is "made in an arm'slength negotiation by experienced and sophisticated businessmen, . . . absent some compelling and countervailing reason it should be honored by the parties and enforced by the courts. ${ }^{39}$ In Carnival Cruise Lines, Inc. v. Shute, ${ }^{50}$ the Supreme Court held that a choice-of-forum clause on a passenger's cruise ticket was valid so long as the passenger had notice and the clause was not created in bad faith. ${ }^{51}$ The logic in Carnival Cruise Lines seems to suggest that at this point the Court is unconcerned with the relative bargaining power of parties to a contract containing a choice-of-court clause. ${ }^{52}$ The Supreme Court has been described by one observer as having a "preoccupation with contract enforcement." ${ }^{33}$

Recent years have shown a theoretical and practical discontent with the Supreme Court's ignorance of the potential pitfalls of deference to contract. Scholars have disparaged the harsh result of constantly relying on the autonomy of the parties. ${ }^{54}$ They have suggested alternatives ranging from the evaluation of a contract's fairness to the parties as a factual question, ${ }^{55}$ and the striking of terms that contravene "strong" default rules, ${ }^{56}$ to a presumption of

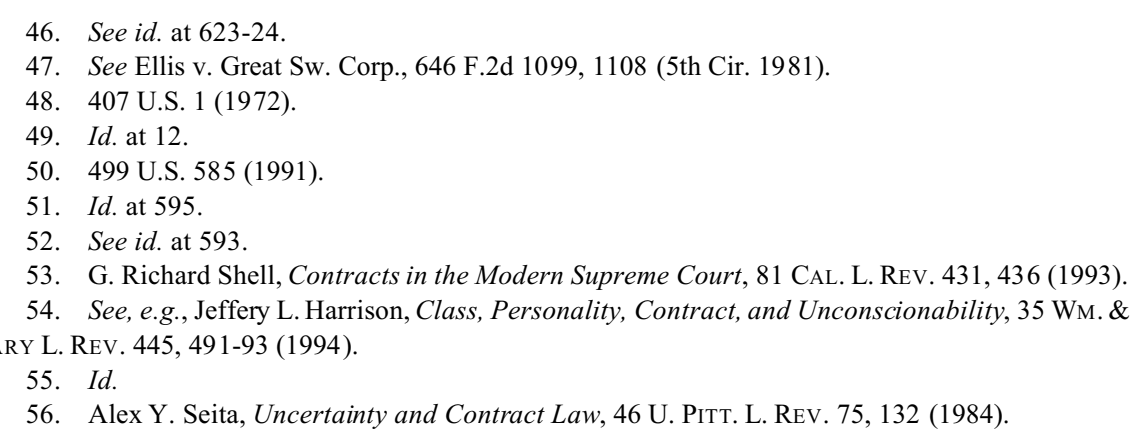


unenforceability of form terms ${ }^{57}$ Litigants have asked courts more frequently to entertain the notion that all or part of the contract suffers from unconscionability, and courts have more consistently agreed. ${ }^{58}$

The courts have been most consistently active in invalidating clauses that proscribe one's right to sue in court. Arbitration clauses, despite the possible protection of the New York Convention and the Federal Arbitration Act (FAA),${ }^{59}$ are likely to be subject to scrutiny and rendered unenforceable. ${ }^{60}$ Professor Susan Randall believes that the courts in this context are treating arbitration "differently" than other contract clauses. ${ }^{61}$ While it is beyond the scope of this Note to question the legality of such disparate treatment for purposes of the FAA, the language of the cases themselves reveals a specific concern for the substantive unconscionability of subjecting a party to an expensive foreign tribunal that would exact high travel and transaction costs. ${ }^{62}$

In Comb v. PayPal, Inc., the court refused to enforce a forum-selection clause in an arbitration agreement that would have required a consumer to arbitrate any claims against the defendant in a Santa Clara, CA, arbitration house. ${ }^{63}$ Using a reasonableness standard, the court found that the "arbitration clause serves to shield PayPal from liability instead of providing a neutral forum in which to arbitrate disputes. ${ }^{\circ 4}$

Neither have courts been entirely kind to agreements to litigate over this recent period. In Jones $v$. GNC Franchising, Inc. ${ }^{65}$ the court invalidated a forum-selection clause that would have required a California franchisee to litigate a franchise agreement in Pennsylvania. ${ }^{66}$ Applying Bremen, ${ }^{67}$ the Jones court held that the forum-selection clause violated California's strong

57. Todd D. Rakoff, Contracts of Adhesion: An Essay in Reconstruction, 96 HaRv. L. Rev. 1174, $1176(1983)$.

58. See Susan Randall, Judicial Attitudes Towards Arbitration and the Resurgence of Unconscionability, 52 BufF. L. REv. 185, 194 (2004) (describing a study that found 235 reported cases in 2002-2003 involving an unconscionability defense to contract - an increase of over $400 \%$ over twenty years - and, of those 235,100 judgments of unconscionability by the courts).

59. 9 U.S.C. $\S \S 1-16(2006)$. Section 2 specifically provides that contractual agreements to arbitrate are "valid, irrevocable, and enforceable, save upon such grounds as exist at law or in equity for the revocation of any contract." Id. § 2 .

60. See Randall, supra note 58, at 214-16.

61. See id. (describing courts' willingness to uphold similar clauses that do not involve arbitration).

62. See, e.g., Comb v. PayPal, Inc., 218 F. Supp. 2d 1165 (N.D. Cal. 2002) (describing arbitration clauses as an attempt "to shield [defendant] from liability").

63. Id. at 1177 .

64. Id.

65. 211 F.3d 495 (9th Cir. 2000).

66. Id. at 497-98.

67. See infra notes $48-49$ and accompanying text. 
public policy of preventing its residents from being subjected to harmful foreign litigation. ${ }^{68}$ This policy was embodied in a California statute restricting the operation of such clauses. ${ }^{69}$ At least one other court has used a similar statute to invalidate a forum-selection clause. ${ }^{70}$

Combining the logic of Comb and Jones, courts are likely amenable to at least some sort of argument where extreme forum-selection clauses in international contracts could be invalidated. Comb provides a framework for arguing that forum selection can be used as a tool to dissuade dispute resolution. Its logic is just as applicable to litigation as to arbitration. Jones indicates that courts are concerned about business-to-business contracts that may impinge upon the ability of smaller domestic businesses to fully defend themselves or litigate wrongdoing.

I do not contend that forum-selection clauses should be per se invalid. It is likely that, much of the time, the rule supporting enforcement of forum selection clauses reaches a result that is at once just and efficient. However, Comb suggests that there might be times where a forum is not selected to reduce costs and provide a centralized location for grievances, but rather to oppress a contrary party. I contend that courts should be wary of this possibility and apply both determinations on the bargaining power of the parties and notions of forum non conveniens to their analyses.

\section{The Development and Implementation of the Hague Convention AND its EFfect on Forum Non CONVENiens}

\section{A. History: The Abandoned Preliminary Draft Convention and the Current Convention}

In the 1970s, the Hague Conference on Private International Law adopted two treaties pertaining to civil jurisdiction. ${ }^{71}$ These treaties were not ratified widely enough to create significant effect. ${ }^{72}$ In 1996, after numerous requests

68. Jones, 211 F.3d at 497-98. The court discussed but did not rule on the other prong of the Bremen test-namely that the clause might be unenforceable if the plaintiff could show that it would, for all practical purposes, deprive him "of his day in court." Id. at $497 \mathrm{n} .11$ (quoting M/S Bremen v. Zapata Off-Shore Co., 407 U.S. 1, 18 (1972)).

69. Id. at 498 .

70. See Keystone, Inc. v. Triad Sys. Corp., 971 P.2d 1240 (Mont. 1998).

71. Convention on the Recognition and Enforcement of Foreign Judgments in Civil and Commercial Matters, Feb. 1, 1971, 1144 U.N.T.S. 271; Convention on the Recognition of Divorces and Legal Separations, June 1, 1970, 8 I.L.M. 31.

72. Ronald A. Brand, Intellectual Property, Electronic Commerce and the Preliminary Draft Hague 
from the United States, the Hague Conference began work on another treaty "on jurisdiction, recognition and enforcement of judgments in civil and commercial matters." "73 Professor Ronald Brand notes that the intent was to codify a system of determining whether or not any court anywhere in the world could or must hear a case - sort of a corollary to the EU's Brussels Regulation $^{74}$ or the U.S.'s Due Process and Full Faith and Credit Clauses for the entire world. ${ }^{75}$ The Hague Conference completed work on the Preliminary Draft Convention (PDC) in 2001, and many commentators expected that this treaty, although described as opaque and suffering from a number of problems, would be ratified in some form. ${ }^{76}$ However, the rules this convention created were unacceptable to the United States, and the PDC was abandoned for a smaller, more palatable project on jurisdiction as it pertained to the use of choice-of-court clauses. ${ }^{77}$ This project eventually became the Hague Convention.

The current Hague Convention has been described as a litigation counterpart to the New York Convention. ${ }^{78}$ It applies only to business-tobusiness contracts with "exclusive" choice-of-court clauses. ${ }^{79}$ It sets up a presumption that a choice-of-court agreement is exclusive where only one court or country is named.$^{80}$ Generally speaking, courts named in exclusive choice-of-court clauses have jurisdiction. ${ }^{81}$ Conversely, courts not named in exclusive choice-of-court clauses do not have jurisdiction and are required to decline to hear the case. ${ }^{82}$ Judgments reached in accordance with the Hague Convention are to be recognized and enforced in courts of member states. ${ }^{83}$

Even though the PDC was ultimately abandoned, the Hague Conference's original research into judicial discretion to decline jurisdiction influenced the text of the current Hague Convention. ${ }^{84}$ Early research was concerned with the problems presented for such a treaty where individual countries had

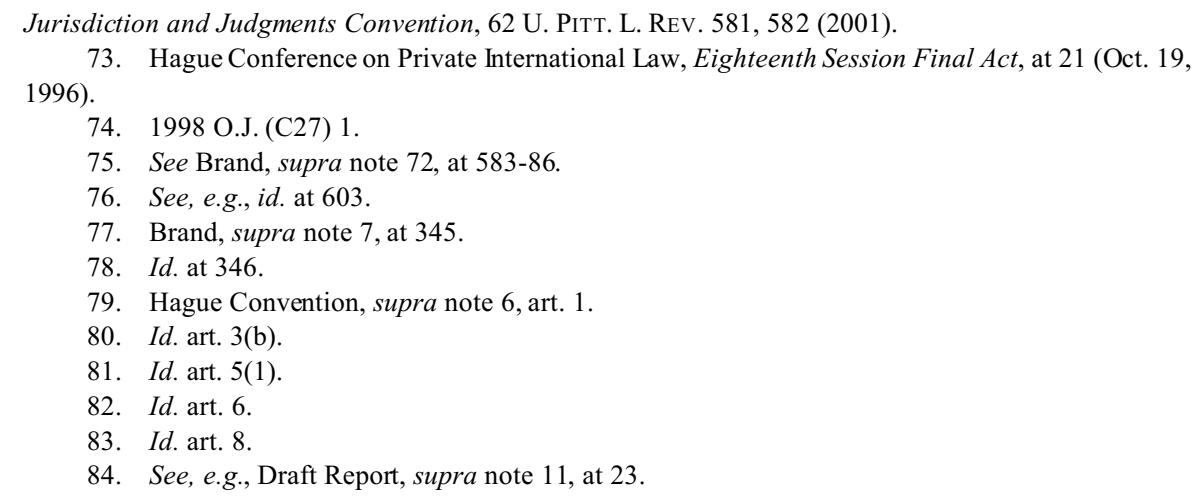


developed disparate and often confusing guidelines for declining jurisdiction. ${ }^{85}$ Drafters emphasized that it is essential for the functioning of a treaty on jurisdiction that at least one court empowered to hear the case must be required to do so $;^{86}$ otherwise, the entire codification of when to hear or not to hear a case reverts to the current system of a judiciary interpreting vague and broad standards.

\section{B. Article 5}

\section{The Rule}

The drafters solved the problem described above by inserting the brightline rule of Article $5 .^{87}$ Courts chosen by the parties are stripped of their discretion to decline to hear the dispute. ${ }^{88}$ There are two exceptions. First, a court may decline jurisdiction where the agreement is null and void under the law of the state of the chosen court. ${ }^{89}$ Given the United States' reluctance to invalidate choice-of-court clauses based on unequal bargaining power of the parties, ${ }^{90}$ however, this exception may not come into play in domestic courts. Second, the Hague Convention specifically allows member states to allocate jurisdiction internally without violating the treaty. ${ }^{91}$ It requests that "due consideration be given to the choice of the parties," but transfer is still an option. $^{92}$

\section{Procedural Critiques of Article 5}

The frustration undoubtedly felt by the Hague Conference in drafting a clause to deal with forum non conveniens and related doctrines is understandable. Jurisprudence in this area has been referred to as "a crazy

85. See generally Hague Conference on Private International Law, Note on the Question of "Forum Non Conveniens" in the Perspective of a Double Convention on Judicial Jurisdiction and the Enforcement of Decisions, Prelim. Doc. No. 3 (Apr. 1996), available at http://www.hcch.net/upload/wop/jdgm_ pd03(1996).pdf.

86. Draft Report, supra note 11, at 23.

87. Hague Convention, supra note 6, art. 5(2).

88. Id. Note, however, that the Hague Convention specifically requires subject matter jurisdiction to exist independent of the treaty. See id. art. 5(3)(a).

89. Id. art. 5(1).

90. See supra notes $48-53$ and accompanying text.

91. Hague Convention, supra note 6, art. 5(3)(b).

92. Id.; see Draft Report, supra note 11, at 23 ("“A]rticle 5(2) would not preclude a transfer to a federal court in a different state of the United States of America."). 
quilt of ad hoc, capricious, and inconsistent decisions. ${ }^{\circ 3}$ Some experts have also noted that the doctrine enables savvy defendants, especially large U.S. corporations doing business abroad, to avoid litigation in their home forum for torts committed abroad. ${ }^{94}$ These critiques notwithstanding, the text of Article 5 presents various problems that require Congress's attention when considering ratification.

First, as often occurs with bright-line rules, Article 5 is over-inclusive. While the general rule of freedom of contract is a highly lauded general principle of developed legal systems the world over (especially in the U.S.), it may not always be the best default. ${ }^{95}$ There are several reasons to question the wisdom of granting parties absolute, unsupervised autonomy in the decision of what court can hear their case. ${ }^{96}$ Arguably, however, this is precisely the rule in the New York Convention, and contract drafters have relied on this rule effectively for decades. ${ }^{97}$ This view ignores the essential nature of courts as official state organs. Courts are in the business of administering justice for their respective territories, quite different from an arbitration house's charge of hearing disputes for paying customers while maximizing profit. Returning to the original hypothetical, it seems unrealistic to expect Arkansas to expend taxpayer dollars and the time of a trial court to hear cases that have no connection to the forum solely because of a perceived expertise or bias in cases involving large retail chains.

Second, the concern about trials in unconnected venues is exacerbated by the ability of parties such as those in the hypothetical to research their court choice and engage in pre-emptive forum shopping. Parties could use Article 5 to designate courts with favorably-minded judges, auspicious conflict rules, or simply a court that is so inconvenient for the other party that entering litigation is discouraged and defending a claim is prohibitively expensive. Put simply, the policy concerns for private and public interests laid out by the Piper $\operatorname{court}^{98}$ remain pertinent despite the Hague Conference's attempt to ignore them.

93. Allan R. Stein, Forum Non Conveniens and the Redundancy of Court Access Doctrine, 133 U. PA. L. Rev. 781, 785 (1985).

94. Peter J. Carney, International Forum Non Conveniens: "Section 1404.5"-A Proposal in the Interest of Sovereignty, Comity, and Individual Justice, 45 AM. U. L. REv. 415, 451-52 (1995).

95. See Jeffrey A. Liesemer, Note, Carnival's Got the Fun . . . and the Forum: A New Look at Choice-of-Forum Clauses and the Unconscionability Doctrine After Carnival Cruise Lines, Inc.v. Shute, 53 U. PitT. L. Rev. 1025, 1056-57 (1992).

96. See supra text accompanying notes 54-70.

97. New York Convention, supra note 4, art. II(1).

98. Piper Aircraft Co. v. Reyno, 454 U.S. 235, 251-52 (1981). 
Third, the Hague Convention explicitly does not apply to tort claims. ${ }^{99}$ Presumably, a court that may not decline jurisdiction over a Hague Convention claim may still apply its own rules for declining jurisdiction on supplemental claims. Assume that a Little Grill Guy product spontaneously combusted in a Tokyo-Mart in Sapporo, injuring customers. Tokyo-Mart now wishes to bring a breach of contract claim against Little Grill Guy, as well as a claim for indemnification against any award those injured customers might receive in Japan against the deep pockets of Tokyo-Mart. The Arkansas court could conceivably decline to hear the indemnification claim based on the Piper analysis for forum non conveniens without violating the treaty. ${ }^{100}$ Tokyo-Mart would be free at this point to file a claim in the Allegheny County Court of Common Pleas - the state-level court of the county where LGG resides - or in Japan (provided, of course, that Japanese jurisdictional and venue rules create sufficient power to hale Little Grill Guy into court). The litigants and the court system are now faced with resolving two separate proceedings on substantially the same set of facts, separated by the lack of a uniform rule.

\section{Article 5, State Courts, and the Constitution}

Article 5 calls into question not only matters of American civil procedure but could create constitutional difficulties. Suppose Little Grill Guy is actually Petit Gars de Gril, a corporation with its primary place of business in Marseilles, France. The form contract still contains the same choice-of-court clause, and Tokyo-Mart files suit in Bentonville. This fact pattern now bears some similarity to a Supreme Court case concerning the exercise of a court's jurisdiction and its impact on interstate commerce.

In Davis v. Farmers ' Co-operative Equity Co., ${ }^{101}$ the Court considered an assertion of jurisdiction by a Minnesota court over a dispute between two parties engaged in the shipment of grain in Kansas. ${ }^{102}$ The shipment never entered Minnesota. ${ }^{103}$ The two parties involved were Kansas corporations "in no way connected with Minnesota." 104 The Minnesota court asserted jurisdiction by relying on an interpretation of a jurisdictional statute which

99. Hague Convention, supra note 6 , art. 2(2)(k).

100. Piper Aircraft Co., 454 U.S. at 257.

101. 262 U.S. 312 (1923).

102. Id. at 314 .

103. Id.

104. Id. 
made any firm amenable to service of process where it had an agent in the state for the purpose of soliciting freight or passenger traffic. ${ }^{105}$ In reversing the decision, the Court held that such a far-reaching jurisdictional assertion would be "obnoxious to the [C]ommerce [C]lause."106 Justice Brandeis reasoned that such a statute would subject anyone doing business as a carrier to suit in that state, or any other state that saw fit to enact such a statute. ${ }^{107}$ As the orderly administration of interstate transportation is in the interest of interstate commerce, to uphold the jurisdictional and venue statute would impinge upon that interest. ${ }^{108}$

At least one commentator critiqued this constitutional theory of declining jurisdiction as "short-lived," reasoning that it is implicitly overruled by forum non conveniens. ${ }^{109}$ However, the Gulf Oil court favorably cited the Davis decision, saying that "the use of an inappropriate forum" could be "an unconstitutional burden on interstate commerce." ${ }^{110}$ Also, commentators have praised the rationale behind this rule. ${ }^{111}$

Like the Minnesota court in Davis, state courts empowered by the Hague Convention could undoubtedly pose a substantial burden to interstate commerce. Resolving a dispute unrelated to the adjudicating court would likely foster an increase in the costs and length of litigation to the point where state courts become a wrench in the gears of international business. Extending to such a court the right to hear a dispute just because the parties chose the forum would lead to parties exiting the international market for fear of protracted, overly costly litigation.

Unlike the assertion of jurisdiction in Davis, the Hague Convention would be somewhat protected by Congress's Treaty Power and the Supremacy Clause. Perhaps Congress is relinquishing its right to control interstate commerce by passing such a treaty. Still, this protection presents a theoretical concern. Congress would be utilizing a constitutional provision to protect a constitutional violation. Arguably, the power of Congress to approve treaties,

105. Id. at 314,315 .

106. $I d$.

107. See id.

108. $I d$.

109. See Ann Alexander, Forum Non Conveniens in the Absence of an Alternative Forum, 86 Colum. L. Rev. 1000, 1001 n.9 (1986).

110. Gulf Oil Corp. v. Gilbert, 330 U.S. 501, 505 (1947).

111. See, e.g., David W. Robertson, The Federal Doctrine of Forum Non Conveniens: "An Object Lesson in Uncontrolled Discretion,” 29 Tex. InT'L L.J. 353, 379 (1994); Russell J. Weintraub, Commentary on the Conflict of Laws 211 (3d ed. 1986). 
and the constitutional authority granted to those treaties, does not extend to the possibility that those treaties may upset the constitutional order.

Experts have confronted just this issue earlier in the planning process for the Hague Convention. When the Hague Conference was contemplating a broader based treaty for jurisdiction in civil and commercial matters, American experts were divided on the question of whether U.S. notions of appropriate jurisdiction would trump those of the treaty. ${ }^{112}$ Professor Andrew Strauss argued that the Constitution recognizes the difference between internal power (left to domestic organs) and external power (left to international law) $;{ }^{113}$ because jurisdiction is about allocation of power to sub-units, Professor Strauss argued that it is to be administered externally and thus the treaty would trump jurisdictional doctrine. ${ }^{114}$ Professor Cox argued that limits on jurisdiction apply to Congressional attempts to authorize jurisdiction; ${ }^{115}$ thus, domestic understanding on limits on jurisdiction must trump the treaty. ${ }^{116}$

These professors analyzed the problem before the treaty was trimmed down to simply a contractual analysis, and their concerns are more about Due Process limits on the empowerment of courts rather than other potential constitutional limits on inconvenient forums, but the divide on the new issue is likely to mirror the old debate. Could limits on states' ability to affect interstate commerce thus limit Congress's ability to authorize the abrogation of those limits? Or could this problem be characterized as Congress actually regulating interstate commerce by delegating authority to the states? ${ }^{117}$

Practically, however, even if one resolves the conflict in favor of the treaty, the logic behind the dormant Commerce Clause still exists. States should not hamper interstate commerce, regardless of their intentions. ${ }^{118}$ The

112. See generally Patrick J. Borchers, "Could a Treaty Trump Supreme Court Jurisdictional Doctrine?" Introductory Remarks, 61 ALB. L. REv. 1159 (1998). Because this Note is concerned with the common law doctrine of forum non conveniens, and the problem has assumed that the jurisdictional issues are not before the courts, the Due Process problems presented by the current Hague Convention are beyond the scope of the Note.

113. Andrew L. Strauss, Where America Ends and the International Order Begins: Interpreting the Jurisdictional Reach of the U.S. Constitution in Light of a Proposed Hague Convention on Jurisdiction and Satisfaction of Judgments, 61 ALB. L. REv. 1237, 1246 (1998).

114. Id. at 1249-50.

115. Stanley E. Cox, Why Properly Construed Due Process Limits on Personal Jurisdiction Must Always Trump Contrary Treaty Provisions, 61 ALB. L. Rev. 1177, 1187 (1998).

116. Id. at 1203 .

117. This solution seems to beg the question answered by the Supreme Court in Printz v. United States, 521 U.S. 898 (1997), where the Court invalidated a statute pressing state officials into action for the federal government

118. For examples of non-discriminatory state actions that impinged severely on state action, see Raymond Motor Transp., Inc. v. Rice, 434 U.S. 429 (1978) and Pike v. Bruce Church, Inc., 397 U.S. 137 
federal system of uniform and smooth interstate and international commerce is a factor in the U.S.'s rise to dominance in this context and should not be disturbed.

\section{A Proposal for Congressional Action to Resolve Differences Between American Jurisprudence and the Hague Convention}

The United States must act to ensure the healthy functioning of its judiciary under the Hague Convention. Congressional legislation can ensure that courts are not overburdened, parties are not abused, and the constitutional system sits undisturbed. My proposal for such congressional action is threefold. First, Congress should enact legislation providing federal question jurisdiction for breach-of-contract cases involving international contracts that contain a choice-of-court clause. This would allow parties like LGG, who are subject to unfavorable choice of court agreements (especially those not negotiated at arms length), to move for removal to federal court. Second, when ratifying the treaty, Congress and the President should include a declaration that it interprets Article 5(3)(b) as being consistent with 28 U.S.C. $\S \S 1404,1406$. This would give domestic defendants who successfully remove to federal court the opportunity to transfer the case to a more convenient forum. Lastly, the Executive and Congress should file a narrow declaration to Article 5 which would prevent forum non conveniens dismissals in cases where the contractually named forum has no connection to the dispute and an alternative, more convenient forum only exists abroad. These steps are discussed in more detail below, along with alternative solutions that are ultimately insufficient.

\section{A. Legislation to Create Federal Question Jurisdiction So As to Allow For Removal}

This step is likely superfluous; most often, parties engaged in this sort of litigation will satisfy the diversity requirements of federal jurisdiction ${ }^{119}$ and can remove in that manner without new legislation. ${ }^{120}$ The concern over inconvenient litigation is lessened where the suit takes place in the defendant's home forum, so removal is not as urgent in this situation. ${ }^{121}$ Still,

(1970).

119. 28 U.S.C. $\S 1332(2006)$.

120. Id. $\S 1441$.

121. Although the Piper court did recognize that litigation can be inconvenient in the home forum, 
the Hague Convention may apply to many small contracts that do not reach the amount-in-controversy requirement. ${ }^{122}$ Congress is certainly within its Commerce Clause or Treaty Clause powers to enact legislation providing federal question jurisdiction for international business-to-business contracts covered by the Hague Convention. A suggested text is below:

\begin{abstract}
Any person who breaches an international contract for civil or commercial matters that contains a choice-of-court clause to which the Hague Convention on Choice of Court Agreements applies shall be liable to the non-breaching party in an action at law, suit in equity, or other proper proceeding for redress in a District Court of these United States. Remedies for this breach are to be determined by the law applicable to the contract.
\end{abstract}

Such a text would give parties that are concerned about their ability to effectively represent themselves in a far away state court the ability to remove the case to federal court. Because the removal statutes only allow defendants to remove, there is very little potential for domestic firms to game their business partners by disingenuously agreeing to an inconvenient forum only to sue and immediately remove the case. ${ }^{123}$ The protection sought here is primarily intended for domestic defendants, who would be assured by this legislation that their dispute would not require their presence in an inconvenient state court.

Removal would also lessen the problem of resolving supplemental claims sounding in tort, antitrust, or other matters not covered by the Hague Convention. The removal statutes and supplemental jurisdiction rules would bring along a related claim into federal court, ${ }^{124}$ where the next two legislative actions would prove useful.

\title{
B. A Declaration on U.S. Interpretation of Article 5(3)(b)
}

The United States should file a declaration with its ratification of the Hague Convention stating that its reading of Article 5(3)(b) is consistent with the provisions of 28 U.S.C. $\S \S 1404,1406$. Such a declaration would allow a federal court, when the transfer statutes are satisfied, to move the case to another district court. Thus, domestic defendants could at least ensure that

\footnotetext{
at least there, defendants have protection from foreign bias and access to attorneys they usually use to conduct business. Removal on diversity grounds in this situation is not permitted. See id. $\S 1441$ (b).

122. Id. §1332(a).

123. Id. § 1441(a).

124. Id. § 1367.
} 
litigation in an unconnected forum could be moved to some other forum, either where the events leading to the breach occurred, or if the events occurred abroad, at least to the defendant's home forum. Also, the choice-oflaw rule set out in Van Dusen v. Barrack, ${ }^{125}$ coupled with this declaration, ensures that the parties' choice of law is not unduly disturbed and the use of transfer is only driven by the purpose of making the litigation more convenient. Moreover, the removal-transfer regime suggested does not require that U.S. courts declare the choice-of-court provision in the parties' agreement null and void, as suggested by Article 5; ${ }^{126}$ thus, the U.S. preference for honoring choice-of-court agreements stands firm except in the most unpalatable of cases, and even then only allows a transfer in the interest of convenience.

Despite the protections inherent in the existing statutory scheme for removal and transfer, there is still potential for abuse by domestic firms. Recall the original hypothetical and switch the nationality of the parties such that the retail firm is American and the manufacturer is Japanese. Also, imagine that the American firm is simply unable to negotiate a choice-of-court provision designating their home (here, assume Bentonville, Arkansas) as the chosen court. Given the system just described, the American firm could simply designate some court in the U.S. that would likely never have a significant connection to the dispute, knowing that if it is sued there, it may simply remove and transfer the case back to Bentonville. ${ }^{127}$ Although such a scenario is somewhat less troubling than if the removal statute permitted plaintiffs to transfer, Congress should still protect the freedom of contract from this sort of gaming. To do so, the declaration should include an explanation of Congress's interpretation of "due consideration" in Article 5. ${ }^{128}$ This interpretation should suggest that removal and transfer are appropriate where the forum chosen has no connection to the dispute and justice is better served by a court in another district.

This scheme may not comport with the Hague Convention's understanding of federal systems. In Article 25, the Convention makes clear that in "non-unified" systems (presumably including the American federal system), "any reference to the court or courts of a State shall be construed as referring, where appropriate, to the court or courts in the relevant territorial

125. 376 U.S. 612,639 (1964).

126. Hague Convention, supra note 6, art. 5(3)(b).

127. $\S \S 1404,1406,1441$.

128. Hague Convention, supra note 6, art. 5(3)(b). 
unit." 129 Where a choice-of-court clause refers to "the courts of the State of Arkansas," the Treaty appears to interpret that phrase as referring only to state or federal courts within Arkansas. This definition could possibly operate to prevent the use of $\S 1404$ or $\S 1406$ transfer. Nevertheless, one could argue that transfer remains viable as an exercise of power by the named court. Further, because transfer does not operate as a dismissal, it likely does not prejudice the claim from being heard and simply moves it to a more convenient forum. Still, the possible construction of Article 25 to limit the ability of courts to transfer cases within the federal system may frustrate the plan outlined above.

\section{A Narrowly-Tailored Declaration to Article 5(2)}

As contemplated above, the removal-transfer scheme may simply be too radical a departure from the Hague Convention's treatment of federal systems. If Congress indeed determines that any declaration designed to allow the federal courts to transfer cases to other districts exceeds the proscriptions in Article 25, it should consider an alternative to at least prevent the most egregious abuses of choice-of-court clauses from taking advantage of the Hague Convention.

Further, even if the removal-transfer scheme is implemented as contemplated, it may be insufficient to deal with certain anomalous cases. For example, the removal-transfer scheme described above works well where an appropriate forum exists in the United States. While this may well be the case where at least one of the contracting parties is a U.S. firm, it may not be the case where the parties are all foreign, and the forum was chosen absent any connection to the parties' relationship or the dispute. Parties could choose to do this for a variety of reasons. Perhaps they are impressed with the acumen of the Delaware Chancery Court. Perhaps they recognize a bias in a particular forum. Perhaps they simply realize that the party across the table will be dissuaded from entering suit if the forum is a federal district court in Anchorage.

Whatever the reason, the United States should file a narrowly-tailored declaration to Article 5(2) stipulating that its courts are empowered to decline jurisdiction when the following five conditions are met: 
a. The parties involved in the contract are not U.S. persons and have no connection to the forum other than the choice-of-court agreement;

b. The events that gave rise to the claim did not occur in the forum;

c. The interest factors described in Gulf Oil argue strongly for forum non conveniens dismissal, ${ }^{130}$ especially those related to the public interest ${ }^{131}$

d. The removal-transfer scheme described above would not adequately remedy the issues at play in (c); and

e. Another more convenient forum is available to settle the dispute; if necessary, dismissal will be conditional upon the assent of the parties to jurisdiction and venue abroad.

Courts should utilize this declaration to grant a forum non conveniens dismissal only in the most egregious of cases. Their dismissals should be conditional upon the assent of the parties to another jurisdiction. Because we are concerned with abuses by the plaintiff, and because jurisdiction is most likely not a problem for the plaintiff, courts should not have to worry about an abusive plaintiff simply refusing to assent to any other jurisdiction after a brief amount of discovery and testimony reveals an alternative forum to which the defendant has now agreed. While this conditional dismissal would require the court to resolve that portion of the dispute and thus make factual findings, it is likely that these proceedings would impose less of a nuisance than a comprehensive ruling on the merits.

The Hague Convention itself creates difficulty for this solution. As previously stated, a court not named in the choice-of-court agreement should decline to hear the case according to the Convention. ${ }^{132}$ Therefore, a new forum approached by the two parties just dismissed by the U.S. court might decline to hear the case. However, this general rule likely fades if both parties have acquiesced to the impracticability of their original decision and settled on this new forum.

Some might suggest that even this narrow declaration cuts too closely to the central purpose of the Treaty. After all, the general principle underlying the Hague Convention is that freedom of contract is paramount. If there are any exceptions at all, freedom of contract might lose its force as savvy parties exploit loopholes. However, this declaration affects a very small subset of contracts covered under the Convention. By selecting a U.S. forum, these contracts would likely offend constitutional notions of jurisdiction and venue even before the question of a forum non conveniens dismissal is reached. ${ }^{133}$

130. Gulf Oil Corp. v. Gilbert, 330 U.S. 501, 508 (1947).

131. $I d$.

132. Hague Convention, supra note 6 , art. 6 .

133. See, e.g., Asahi Metal Indus. Co. v. Superior Court, 480 U.S. 102 (1987); Davis v. Farmers' Co- 
The vast majority of international contracts placed at issue in front of a U.S. court would receive a judgment from a U.S. court. Only those that arrive here based solely on a clause that appears illogical or unfair would be declined. Further, such a declaration is explicitly allowed by the Hague Convention; in actuality, the declaration as stated above is even narrower than that contemplated in Article 19. ${ }^{134}$

\section{Other Alternatives, and Their Insufficiencies}

\section{Rejection of the Treaty}

After reading the critique of the Hague Convention's handling of the forum non conveniens question, many readers are likely to question the value of the treaty in general. The U.S. could avoid all of these questions by rejecting the treaty out of hand and relying on its current jurisprudential scheme to decide which cases it hears.

This reaction is overly harsh. The Hague Convention would allow international parties a legitimate choice between arbitration and litigation. The New York Convention has been an overwhelming success, and its general rule of freedom of contract has served the international business community well. ${ }^{135}$ The U.S. in particular would benefit from the Hague Convention because it would ensure that more U.S. judgments are recognized and enforced abroad. This has been a concern for many years as foreign courts are uncomfortable with certain American conventions, such as punitive damages, jury determinations, and the lack of attorney fee awards. ${ }^{136}$ The aim of this paper is not to disparage the Hague Convention; rather, it simply suggests potential conflicts and attempts to resolve them without advocating a wholesale abandonment of what will ultimately be an effective scheme of international law.

op. Equity Co., 262 U.S. 312 (1923).

134. See Hague Convention, supra note 6, art. 19 (requiring only that declarations refusing jurisdiction over exclusive choice-of-court clauses refer solely to cases where the clause is the only connection with the dispute).

135. Catherine A. Rogers, Emerging Dilemmas in International Economic Arbitration: The Vocation of the International Arbitrator, 20 Am. U. INT'L L. REv. 957, 964 n.18 (2005).

136. See Wolfgang Wurmnest, Recognition and Enforcementof U.S. Money Judgments in Germany, 23 Berkeley J. InT'L L. 175, 175 (2005) (“In many countries around the globe, litigation in the United States is perceived as a 'nightmare' due to long-arm jurisdiction statutes, pre-trial discovery proceedings, and the availability of punitive damages - legal instruments often unknown in other jurisdictions."). 


\section{Broad Declaration to Article 5(2)}

One might also consider simply reserving the right of U.S. courts to apply a forum non conveniens analysis to cases governed by the Hague Convention. There are two problems with this suggestion. The first is contemplated in Part III.C supra - namely, that a broad use of forum non conveniens offends the central notion of the Treaty. ${ }^{137}$ Forum non conveniens dismissals are inappropriate for the vast majority of these cases and would result in the treaty losing force and effectiveness. Because the central tenet of the treaty is a valuable one, a broad rejection would not be in the U.S.'s interest. Also, some of the critiques of forum non conveniens as an arbitrary doctrine without predictability or consistency would be alleviated by the proposed narrow declaration. Perhaps the guidance Congress would give on forum non conveniens as it applies to international contract cases would influence the jurisprudence of the courts on declining jurisdiction in other matters.

\section{CONCLusion}

The Hague Convention on Choice of Court Agreements provides businesses with the opportunity to enforce a favorable judgment on a breach of contract in other countries. This is a laudable position. Still, its rule presents concerns for firms out-bargained into a clause that provides them no meaningful opportunity for dispute resolution, as well as for the courts charged with resolving such disputes. By adapting pre-existing procedural safeguards to conform to the new realities of the Treaty, the U.S. can provide parties with protection from, and courts with a framework for curing, these problems. 